\title{
Hepatocyte-specific Bid depletion reduces tumor development by suppressing inflammation-related compensatory proliferation
}

\author{
A Wree ${ }^{1}$, CD Johnson ${ }^{1}$, J Font-Burgada ${ }^{2}$, A Eguchi ${ }^{1}$, D Povero ${ }^{1}$, M Karin ${ }^{2}$ and AE Feldstein ${ }^{*, 1}$
}

Liver cancer is a major health-care concern and its oncogenic mechanisms are still largely unclear. Persistent hepatocyte cell death is a common feature among various chronic liver diseases, the blocking of which presents as logical treatment. Therefore, we aimed at investigating tumor development in mice with hepatocyte-specific Bid depletion - a BH3-only Bcl-2 family member that amplifies apoptotic death signals. Hepatocyte-specific conditional Bid-knockout mice (Bid ${ }^{\text {hep }}$ ) were injected with $25 \mathrm{mg} / \mathrm{kg}$ diethylnitrosamine (DEN) at 14 days of age, and liver tumorigenesis was investigated 9 months later. Additionally, different models of acute liver injury were used including: acute high-dose DEN challenge, 3,5-diethoxycarbonyl-1,4-dihydrocollidine (DDC) diet and carbon tetrachloride (CCL4) injection. Bid ${ }^{\text {hep }}$ mice developed significantly fewer tumors, showed smaller maximal and average tumor size and reduced tumor incidence. In the acute DEN model, $48 \mathrm{~h}$ post injection we observed a significant reduction in liver injury in Bid $^{\Delta \text { hep }}$ animals, assessed via serum transaminases and liver histopathology. Furthermore, TNF- $\alpha$, IL-1B, cJUN and IL- 6 mRNA expression was reduced. These findings were accompanied by reduced compensatory hepatocyte proliferation in Bid ${ }^{\Delta \text { hep }}$ mice when compared with controls by immunohistochemistry for Ki67 and proliferating cell nuclear antigen $48 \mathrm{~h}$ after DEN injection. In the acute CCL4 model, Bid ${ }^{\Delta \text { hep }}$ mice displayed reductions in liver injury and inflammation when compared with controls. No differences in liver injury and serum bilirubin levels were detected in Bid ${ }^{\text {hep }}$ and Bid ${ }^{\text {floflo }}$ mice fed with DDC, which induces bile duct injury and a ductular reaction. Our study demonstrates that in DEN-induced hepatocellular carcinoma, the inhibition of hepatocyte death pathways through Bid deletion protects animals from tumorigenesis. These results suggest that reducing hepatocyte cell death, liver inflammation and compensatory proliferation has a stronger beneficial effect than the potential side effect of enhancing tumor cell survival.

Cell Death and Differentiation (2015) 22, 1985-1994; doi:10.1038/cdd.2015.46; published online 24 April 2015

Liver cancer is a major health-care concern with diverse etiology. Viral hepatitis, alcoholic liver disease, carcinogen exposure and metabolic liver diseases are known major causes. ${ }^{1}$ Recent studies indicate that the incidence of hepatocellular carcinoma $(\mathrm{HCC})$ is rising in the westernized world. Since effective and established chemotherapeutic agents for HCC are currently unavailable and its recurrence rate is high, the overall prognosis of $\mathrm{HCC}$ remains poor. The development of HCC, accounting for $\sim 75 \%$ of primary malignant liver tumors, has also been linked to chronic viral infections, alcoholic and non-alcoholic fatty liver disease, to exposure to toxic chemicals, such as polycystic aromatic hydrocarbons and nitrosamines, and is more frequently found in patients with preexisting liver cirrhosis and liver inflammation. ${ }^{2,3} \mathrm{HCC}$ that closely resembles the human disease can be induced in mice with a single postnatal injection of the tumor initiator diethylnitrosamine (DEN). ${ }^{4}$ Many investigators have employed DEN to induce liver tumors in mice by i.p. injecting 14-day-old pups, giving rise to HCC
8-9 months later. ${ }^{5,6}$ In the DEN model, carcinogen-induced DNA damage promotes cell death, causing a Kupffer cellmediated inflammatory response that further stimulates tumor development via hepatocyte compensatory proliferation. ${ }^{7}$

Notably, hepatocyte cell death is a common, yet integral, feature in various chronic liver diseases that result in cirrhosis and hepatocarcinogenesis. Apoptotic cell death has evolved as a pivotal event in several liver diseases. In particular, mounting evidence supports a central role for this form of cell death in liver injury associated with non-alcoholic fatty liver disease (NAFLD), currently the most common form of chronic liver disease in both adults and children that has been linked to HCC development even in the absence of liver cirrhosis. NAFLD has been recognized, as one of the key drivers for the increase in the number of cases of HCC. ${ }^{8,9}$ NAFLD, a spectrum of disorders related to the abnormal accumulation of fat in the liver, affects approximately $20-30 \%$ of the adult population in the United States and many other westernized countries and is closely associated with obesity, insulin

\footnotetext{
${ }^{1}$ Department of Pediatrics, University of California-San Diego, La Jolla, CA, USA and ${ }^{2}$ Laboratory of Gene Regulation and Signal Transduction, Departments of Pharmacology and Pathology, University of California-San Diego, La Jolla, CA, USA

*Corresponding author: AE Feldstein, Department of Pediatrics, University of California—San Diego, 9500 Gilman Drive, MC 0715, La Jolla, CA 92037-0715, USA. Tel: +1 858966 8907; Fax: +1 858966 8917; E-mail: afeldstein@ucsd.edu

Abbreviations: AFP, alphafetoprotein; ALT, alanine aminotransferase; CCL4, carbon tetrachloride; CDAA, choline-deficient amino acid defined; DDC, 3,5-diethoxycarbonyl-1,4dihydrocollidine; DEN, diethylnitrosamine; F4/80, murine macrophage marker; HGF, hepatocyte growth factor; IL, interleukin; mTor, mammalian target of rapamycin; LDH, lactate dehydrogenase; NC, normal chow; PCNA, proliferating cell nuclear antigen; WT, wild type; TNF- $\alpha$, tumor necrosis factor alpha; TUNEL, terminal deoxynucleotidyl transferase dUTP nick-end labeling

Received 08.1.15; accepted 17.3.15; Edited by J Bartek; published online 24.4.15
} 
resistance and type 2 diabetes. ${ }^{10}$ Growing epidemiological evidence link NAFLD to the increase in HCC rates. Moreover, several reports suggest that HCC may arise in histologically confirmed NAFLD without cirrhosis. ${ }^{11-13}$ Improving our understanding of the molecular mechanisms determining HCC development and progression, in particular in the context of NAFLD, is integral to the development of novel therapeutic strategies for this disease. Therefore, the blocking of hepatocyte death pathways, especially apoptotic cell death, presents itself as a logical treatment point of chronic liver disease and, concomitantly, as a preventive measure for liver cancer. However, it is not clear how a general suppression of cell death, especially apoptosis, would affect pre-neoplastic cells, with putative potential to enhance tumorigenesis.

Bid is a BH3-only Bcl-2 family member that is cleaved by caspase-8 into its active form, tBID, which links the extrinsic and intrinsic apoptosis pathways. tBid formation is crucial for amplification of apoptotic death signals in cells like hepatocytes (called type 2 cells), where activation of the mitochondrial pathway is essential for cell death to occur. Bid, however, is dispensable for apoptosis in most other cell types (called type 1 cells). We recently demonstrated that hepatocytespecific BID-deficient mice are resistant to the lethal effects of Fas activation in vivo. ${ }^{14}$ Here, we tested the hypothesis that selective ablation of Bid in hepatocytes modulates the development of liver tumors. Using the hepatocyte-specific Bid knockout mouse - Bid ${ }^{\Delta \text { hep }}$ - model, we show that the inhibition of hepatocyte apoptosis protects from tumorigenesis in two patho-physiologically relevant murine models of HCC. Our data suggest that reducing hepatocyte cell death, liver inflammation and compensatory proliferation has a pronounced beneficial effect vis-a-vis the potential side effect of enhancing tumor cell survival.

\section{Results}

Hepatic Bid depletion protects from DEN-induced tumorigenesis. To address the role of hepatic apoptosis in HCC development, we generated hepatocyte-specific conditional Bid-knockout mice $\left(\mathrm{Bid}^{\Delta \text { hep }}\right.$ ) by crossing AlbCre mice with $\mathrm{Bid}^{\text {flo/flo }}$ mice in the $\mathrm{C} 57 \mathrm{BL} / 6$ genetic background. $\mathrm{Bid}^{\text {flo/flo }}$ animals were employed as controls (Figure $1 \mathrm{~g}$ ). Male mice were injected with DEN 14 days after birth $(25 \mathrm{mg} / \mathrm{kg}$ BW), weaned at day 21, and placed on a normal chow (NC) diet for the duration of the experimental time course. One set of mice was killed 5 months after DEN injection. Livers of these mice- $\mathrm{Bid}^{\Delta \text { hep }}(n=8)$ and $\mathrm{Bid}^{\text {flo/flo }}(n=8)$-did not exhibit any macroscopic tumor development (Figure 1h). However, Bid ${ }^{\text {hep }}$ animals displayed decreased mRNA levels of alpha-fetoprotein (AFP) when compared with $\mathrm{Bid}^{\text {flo/flo }}$ mice (Figure 1f). At the 9-month time point, we found macroscopic tumor development in 7/10 mice in the $\mathrm{Bid}^{\text {flo/flo }}$ mouse group, while only $1 / 10$ animals in the $\mathrm{Bid}^{\text {hep }}$ presented with tumors (Figures $1 \mathrm{a}$ and $\mathrm{b}$ ). This finding translated into a significantly reduced tumor load, significantly decreased maximal tumor size and significantly smaller average tumor size in $\mathrm{Bid}^{\Delta \text { hep }}$ animals when compared with $\mathrm{Bid}^{\text {flo/flo }}$ mice (Figures 1c and e).
$\mathrm{Bid}^{\Delta \text { hep }}$ mice are protected from acute DEN liver damage. The initial cellular damage is known to be of major importance for the incipient development of tumors in the DEN model. Therefore, we assessed liver damage, hepatic cell death and hepatic proliferation in $\operatorname{Bid}^{\Delta \text { hep }}(n=8)$ and $\mathrm{Bid}^{\text {flo/flo }}(n=8)$ animals $48 \mathrm{~h}$ after DEN injection $(100 \mathrm{mg} / \mathrm{kg}$ BW). Gross examination did not detect obvious differences between $\mathrm{Bid}^{\Delta \text { hep }}$ mouse livers and those of $\mathrm{Bid}^{\text {flo/flo }}$ animals (Figure 2a). However, microscopic analysis of Bid ${ }^{\text {flo/flo }}$ livers revealed extensive tissue damage and inflammatory changes mainly surrounding the portal tracks (Figure 2a). Likewise, serum ALT levels were 2 -fold higher in $\mathrm{Bid}^{\text {flo/flo }}$ animals when compared with $\mathrm{Bid}^{\Delta \text { hep }}$ mice (Figure $2 \mathrm{~b}$ ). We observed a greater frequency hepatocyte cell death as assessed by terminal deoxynucleotidyl transferase dUTP nick-end labeling (TUNEL) staining in $\mathrm{Bid}^{\text {flo/flo }}$ animals when compared with $\mathrm{Bid}^{\Delta \text { hep }}$ mice (Figures $2 \mathrm{a}$ and c). Notably, the immunohistochemical quantification of hepatic proliferation markers displayed significantly reduced levels in $\mathrm{Bid}^{\Delta \text { hep }}$ mice when compared with $\mathrm{Bid}^{\text {flo/flo }}$ animals (Figures $2 \mathrm{a}$ and $\mathrm{c}$ ). In line with these results, $\mathrm{Bid}^{\Delta \text { hep }}$ mice displayed significantly reduced mRNA levels of markers of cellular proliferation (Cyclin D1, hepatocyte growth factor (HGF), proliferating cell nuclear antigen (PCNA), mammalian target of rapamycin (mTor, c-Jun) and inflammation (p38a, interleukin 1a (IL1a), IL1b, tumor necrosis factor (TNF), IL6) when compared with Bid $^{\text {flo/flo }}$ mice (Figure 2d).

DEN induced secondary necrosis is reduced in $\mathbf{B i d}^{\Delta \text { hep }}$ primary hepatocytes. Necrotic cell death, resulting in disruption of the plasma membrane and the release of cellular contents into the extracellular space, is associated with a marked inflammatory response that typically induces hepatocyte compensatory proliferation. We hypothesized that the reduction of inflammatory changes and hepatocyte proliferation observed in the $\mathrm{Bid}^{\Delta \text { hep }}$ mice after $48 \mathrm{~h}$ exposure to DEN might be explained in part due to the inhibition of secondary necrotic events induced by massive hepatocyte apoptosis that may overwhelm the capacity for rapid removal of apoptotic bodies resulting in secondary lysis in situ. To test this hypothesis, we isolated hepatocytes from $\mathrm{Bid}^{\Delta \text { hep }}$ and $\mathrm{Bid}^{\text {flo/flo }}$ mice. We treated those cells in vitro with DEN $(100 \mu \mathrm{g} / \mathrm{ml})$, media or $\mathrm{H}_{2} \mathrm{O}_{2}(0.1 \%)$ and performed a timecourse analysis of cell viability. To identify necrotic cells, we added propidium iodide and counterstained with Hoechst to visualize nuclei morphology. As expected, treatment with $\mathrm{H}_{2} \mathrm{O}_{2}$ resulted in necrotic cell death with strong cellular propidium iodide presence as early as $3 \mathrm{~h}$ into the experiment without any genotype-dependent differences (Figure 3a). Cells without additional treatment did not display increased propidium iodide infiltration over the course of $24 \mathrm{~h}$. Interestingly, treatment with DEN did not induce propidium iodide presence at the 3- and 8-h time points consistent with the concept that this chemical induces a pure apoptotic signaling event (Figure 3b). However, $24 \mathrm{~h}$ into the experiment, positive nuclear propidium iodide staining could be detected in DENtreated cells, and these changes were present with a higher signal in $\mathrm{Bid}^{\text {flo/flo }}$ when compared with $\mathrm{Bid}^{\Delta \text { hep }}$ cell populations (Figure $3 \mathrm{c}$ ). Consistent with these findings, quantification of lactate dehydrogenase (LDH) activity in the cell-culture 
a
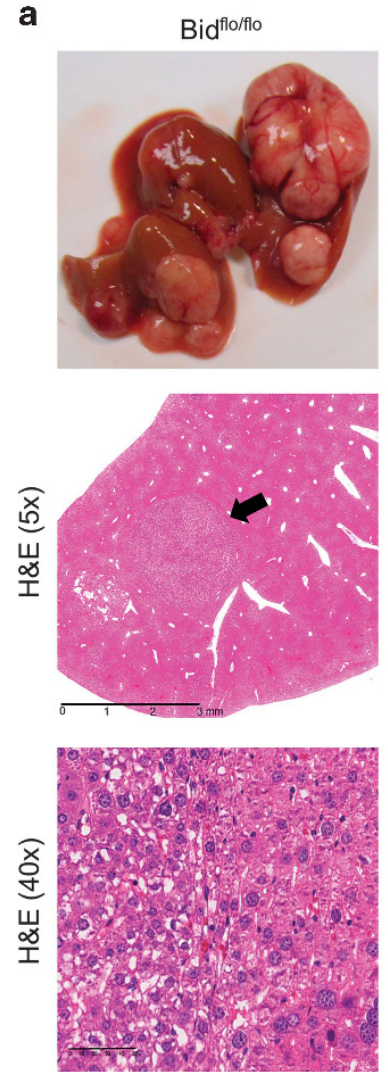

g

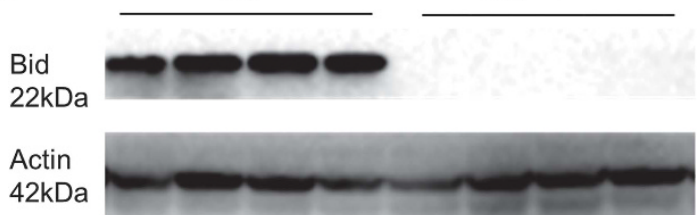

b

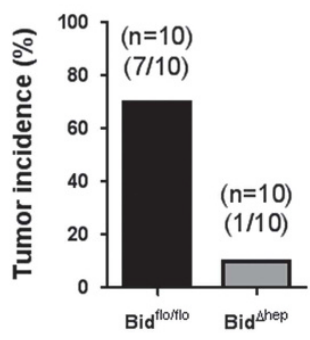

d

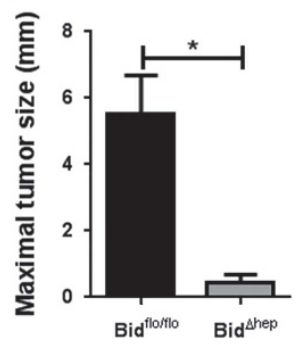

C

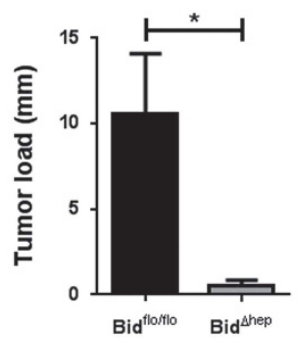

e

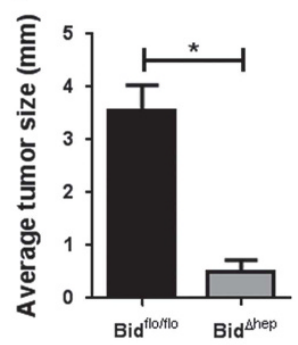

f

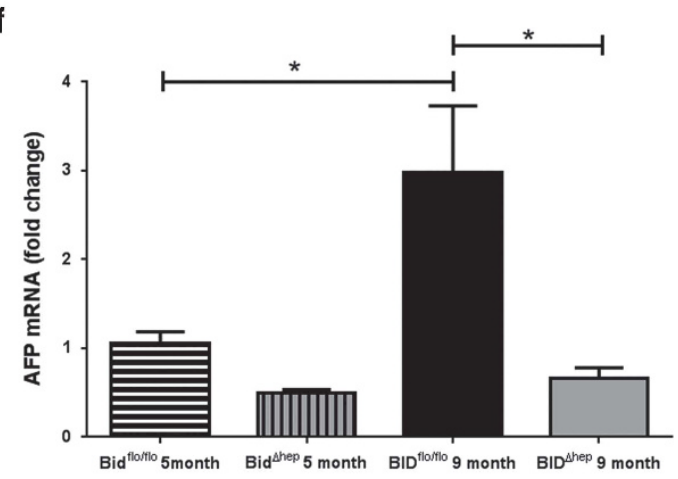

h

\begin{tabular}{|c|c|c|c|c|c|c|}
\hline & \multicolumn{2}{|c|}{ DEN - 5 month } & \multirow[t]{2}{*}{$\mathrm{p}$-value } & \multicolumn{2}{|c|}{ DEN - 9 month } & \multirow[t]{2}{*}{$\mathrm{p}$-value } \\
\hline & $\mathrm{Bid}^{\mathrm{flo} / \mathrm{flo}}$ & $\mathrm{Bid}^{\Delta \text { shep }}$ & & $\mathrm{Bid}^{\mathrm{flo} / \mathrm{flo}}$ & $\mathrm{Bid}^{\Delta \text { thep }}$ & \\
\hline number & 8 & 8 & & 10 & 10 & \\
\hline body weight (g) & $25.85+/-0.28$ & $27.16+/-0.64$ & n.s. \# & $31.25+/-0.72$ & $35.13+/-0.97$ & n.s. \# \\
\hline liver weight (g) & $1.08+/-0.03$ & $1.14+/-0.04$ & n.s. \# & $1.65+/-0.12$ & $1.55+/-0.07$ & $<0.05 \#$ \\
\hline tumor incidence & $0 / 8$ & $0 / 8$ & n.s. \#\# & $7 / 10$ & $1 / 10$ & $<0.05$ \#\# \\
\hline tumor load (mm) & 0 & 0 & n.s. \# & $10.6+/-3.5$ & $1+/-0.45$ & $<0.05 \#$ \\
\hline
\end{tabular}

Figure 1 Male Bid ${ }^{\Delta \text { hep }}$ mice are protected from DEN-induced tumorigenesis. Bid ${ }^{\Delta \text { hep }}$ and Bid ${ }^{\text {floflo }}$ mice on the $\mathrm{C} 57 \mathrm{~b} / 6$ background were injected with DEN 14 days after birth, weaned at day 21 and fed a NC diet. Nine months post injection, Bid ${ }^{\text {hep }}$ mice displayed gross morphological differences in liver tumor formation, a reduction in intra-lobular tumor diameter (a). Further, Bid ${ }^{\text {hep }}$ mice presented with a significant reduction in tumor incidence (b), a significant decrease in tumor load (c) and a significant reduction in both maximal and average tumor size (d, e). Hepatic alpha-fetoprotein (AFP) mRNA levels were reduced in Bid ${ }^{\Delta \text { hep }}$ mice at 5 months post injection when compared with Bid ${ }^{\text {floflio }}$ animals, significantly increased in Bid ${ }^{\text {flloflo }}$ at 9 months when compared with Bid ${ }^{\text {floflilo }}$ mice at 5 months, and showed a significant reduction in Bid ${ }^{\Delta \text { hep }}$ when compared with Bid ${ }^{\text {flofflo }}$ at the 9-month stage (f). Hepatic Bid depletion was confirmed via western blot of liver lysates (g). Liver and body weight measurements 5 months post injection were unremarkable; however, Bid ${ }^{\Delta \text { hep }}$ mice weighed significantly more than Bid ${ }^{\text {floflo }}$ mice 9 months post injection $(\mathbf{h}) .\left({ }^{*} P<0.05 ;{ }^{*}\right.$ Mann-Whitney test; ${ }^{\# \#}$ Fisher's exact test)

supernatant showed increased readings in hepatocytes treated with $\mathrm{H}_{2} \mathrm{O}_{2}$ as early as $3 \mathrm{~h}$ into the study, while LDH activity was comparable in $\mathrm{Bid}^{\text {flo/flo }}$ and $\mathrm{Bid}^{\Delta \text { hep }}$ hepatocytes treated with DEN or media at the 3- and 8-h time points (Figure 3d). DEN-induced LDH signals were different at the 24-h time point with Bid ${ }^{\text {flo/flo }}$ showing significantly increased LDH activity when compared with Bid $^{\text {hep }}$ hepatocytes.

Hepatic Bid deletion is dispensable in predominantly necrotic or cholangiopathic injury. To further explore the 
a
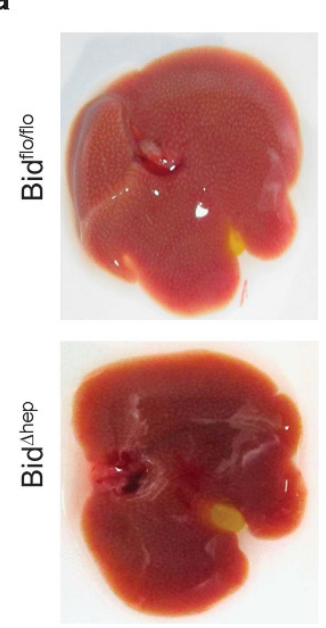

b

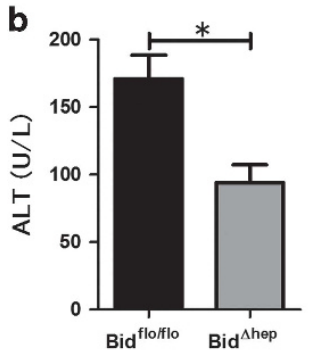

H\&E
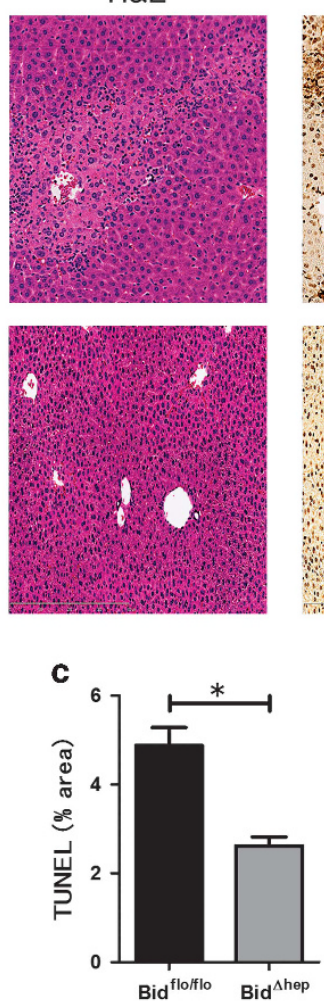

TUNEL
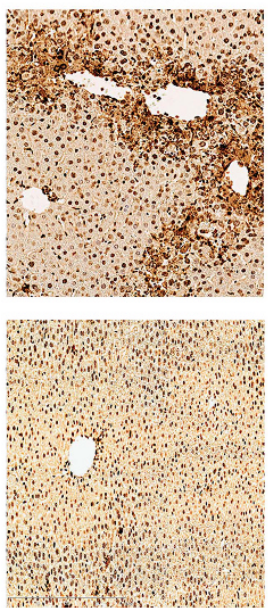

Ki67
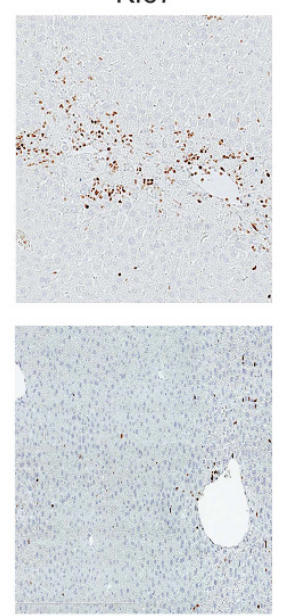

PCNA
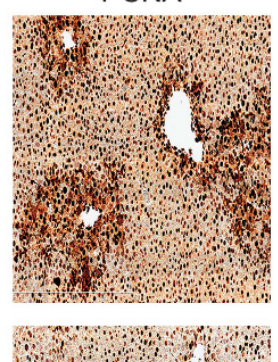
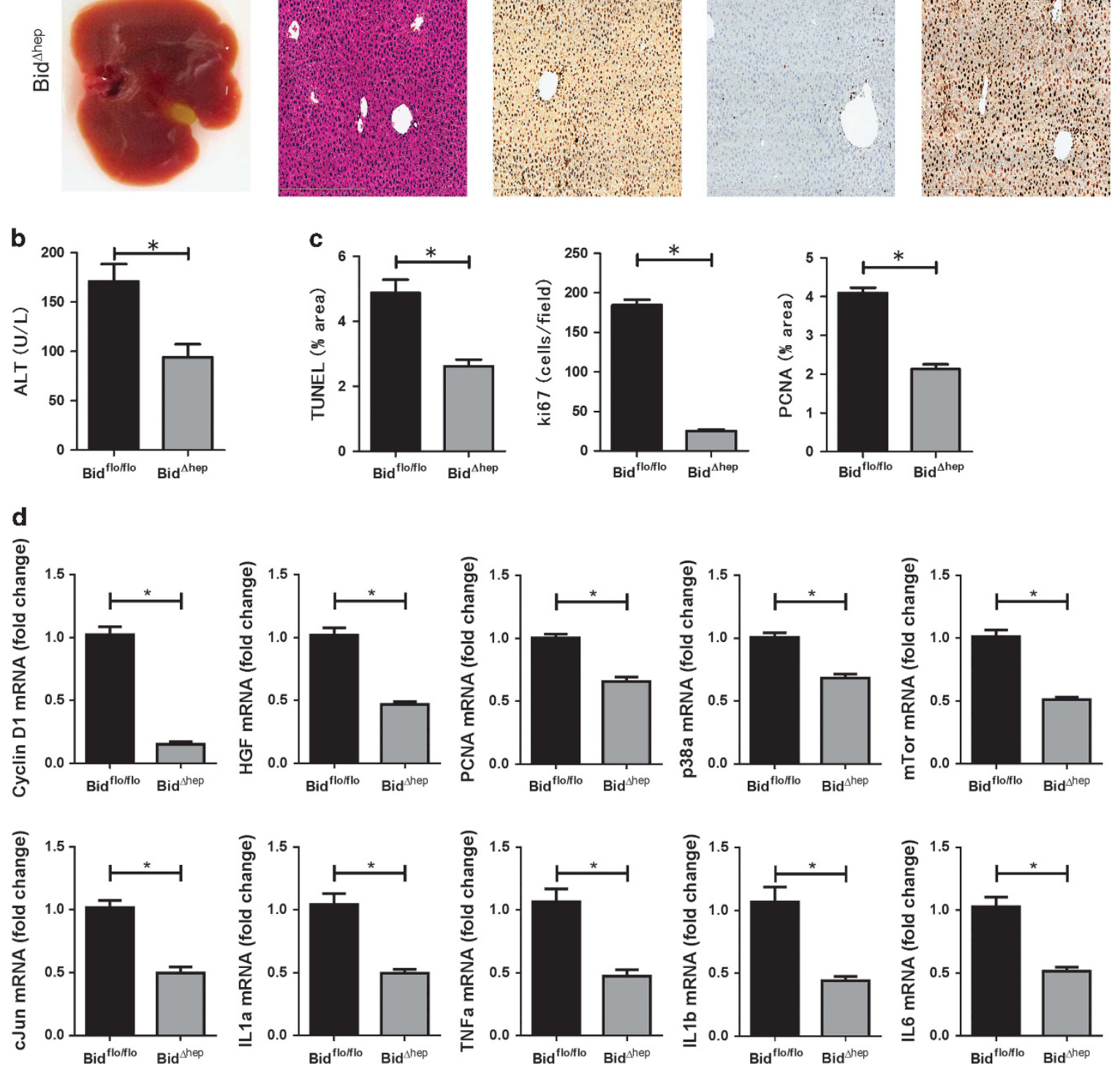

Figure 2 Acute adverse effects of $\mathrm{DEN}-48 \mathrm{~h}$ post injection - are reduced in $\mathrm{Bid}^{\Delta \mathrm{hep}}$ animals. $\mathrm{Bid}^{\mathrm{Ahep}}$ mouse livers were visibly unremarkable from those of $\mathrm{Bid}^{\text {floflil }}$ animals (a). H\&E staining shows major cellular damage surrounding the portal field of Bid ${ }^{\text {flofllo }}$ animals, but peripheral portal field cellular damage is absent in Bid ${ }^{\text {hep }}$ animals (a). Significant differences between Bid ${ }^{\Delta \text { hep }}$ and Bid ${ }^{\text {flloflo }}$ sample groups were detectable in markers of apoptosis (terminal deoxynucleotidyl transferase dUTP nick-end labeling (TUNEL), as well as in several markers of cellular proliferation (ki67, proliferating cell nuclear antigen (PCNA)) (a, c). Bid ${ }^{\Delta \text { hep }}$ mice treated with DEN showed significantly reduced ALT serum levels when compared with Bid ${ }^{\text {flloflo }}$ animals (b). Significantly increased mRNA transcription levels within markers of cellular proliferation (Cyclin D1, hepatocyte growth factor (HGF), PCNA, mammalian target of rapamycin (mTor), c-Jun) and inflammation (p38a, interleukin 1a (IL1a), IL1b, tumor necrosis factor alpha (TNF $\alpha$ ), IL6) were found in $\mathrm{Bid}^{\text {floflio }}$ animals when compared with Bid ${ }^{\Delta \text { hep }}$ mice $\left(\right.$ d) $\left({ }^{*} P<0.05\right)$

concept that the protection from DEN-induced liver injury observed by Bid deletion in hepatocytes was dependent upon the modulation of the apoptotic stimuli triggered by DEN in hepatocytes, we employed two additional models of liver injury: (1) DDC diet for 2 weeks as a model for cholangiopathic injury; (2) CCL4 injection as a model for necrotic cell death. Both models were tested in approximately 8-week-old $\mathrm{Bid}^{\text {flo/flo }}$ and $\mathrm{Bid}^{\Delta \text { hep }}$ animals. Mice fed a DDC diet for 2 weeks 
a
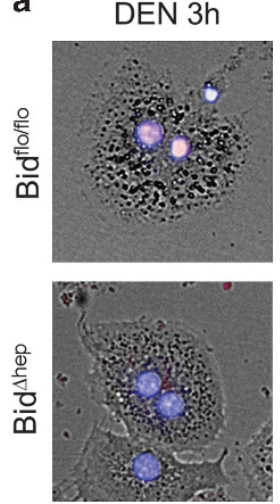

c
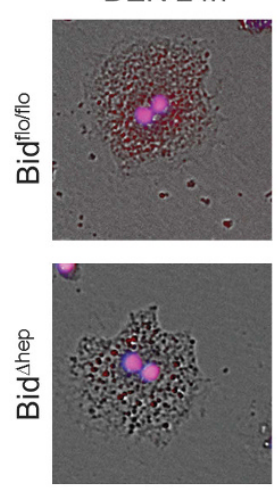

media $3 h$
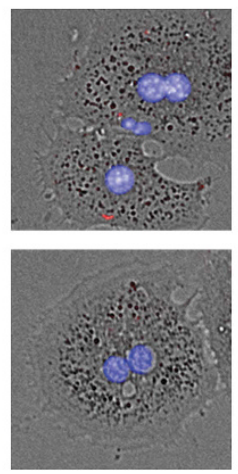

media $24 \mathrm{~h}$
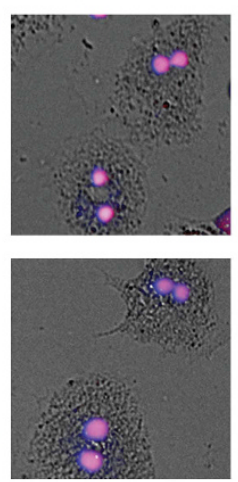

$\mathrm{H}_{2} \mathrm{O}_{2} 3 \mathrm{~h}$
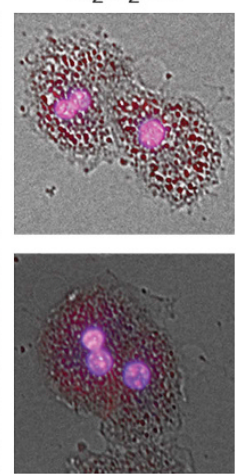

$\mathrm{H}_{2} \mathrm{O}_{2} 24 \mathrm{~h}$
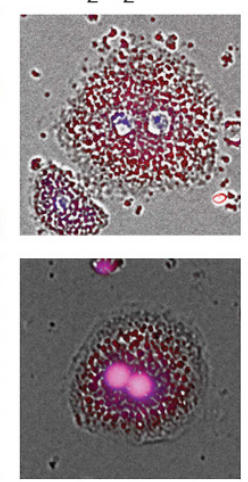

b
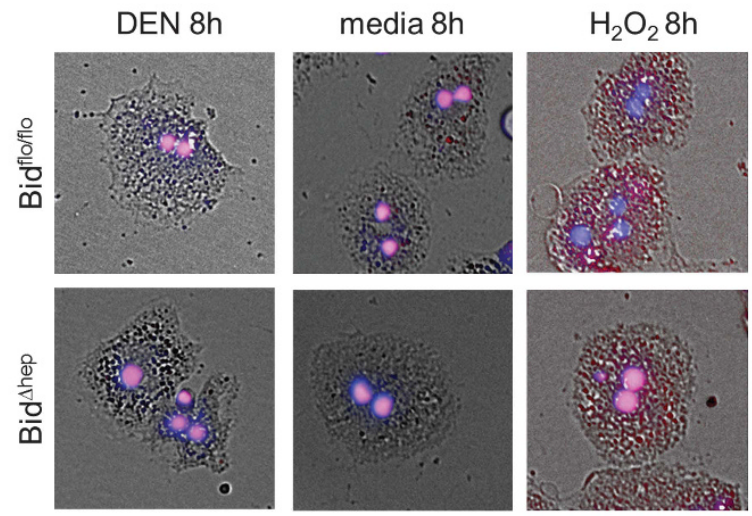

d

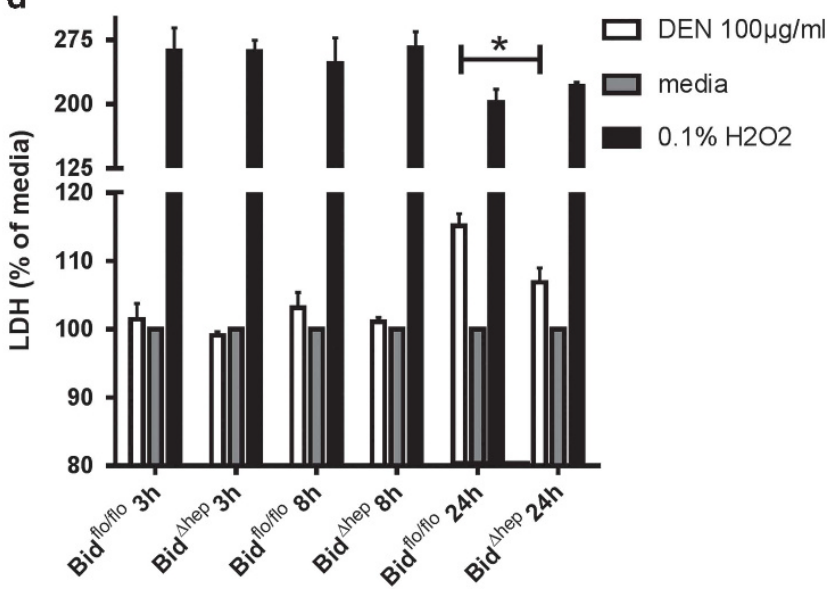

Figure 3 Primary hepatocytes from Bid ${ }^{\Delta \text { hep }}$ mice present decreased secondary necrosis upon DEN treatment. Hepatocytes were isolated from Bid ${ }^{\Delta \text { hep }}$ and Bid ${ }^{\text {flloflo }}$ mice and treated with diethylnitrosamine (DEN, $100 \mu \mathrm{g} / \mathrm{ml}$ ), media or $\mathrm{H}_{2} \mathrm{O}_{2}(0.1 \%)$ over a period of $24 \mathrm{~h}$. Hepatocytes were incubated with propidium iodide to mark necrotic cells and counterstained with Hoechst to visualize nuclei. Hepatocytes treated with $\mathrm{H}_{2} \mathrm{O}_{2}$ displayed strong cellular propidium iodide presence as early as $3 \mathrm{~h}$ into the experiment (a). Cells without additional treatment did not display increased propidium iodide infiltration over the course of $24 \mathrm{~h}(\mathrm{a}-\mathrm{c})$. Hepatocytes treated with DEN exhibited no significant DEN signal at the 3-and 8-h time points. $24 \mathrm{~h}$ into the experiment, DEN treatment induced some cellular propidium iodide presence with a higher signal detected in Bid ${ }^{\text {flofflo }}$ when compared with $\mathrm{Bid}^{\Delta \mathrm{hep}}$. In line with this result, quantification of lactate dehydrogenase (LDH) activity showed increased readings in hepatocytes treated with $\mathrm{H}_{2} \mathrm{O}_{2}$ as early as $3 \mathrm{~h}$ into the study, while LDH activity was comparable in Bid ${ }^{\text {floflo }}$ and $\mathrm{Bid}^{\mathrm{Lhep}}$ hepatocytes treated with DEN or media at the 3- and 8-h time points (d). DEN-induced LDH signals were different at the 24-h time point with Bid ${ }^{\text {floflo }}$ showing significantly increased LDH activity when compared with Bid ${ }^{\Delta \text { hep }}$ hepatocytes $(d)\left({ }^{\star} P<0.05\right)$

displayed increased levels of bilirubin and ALT independent of genotype (Figures $4 \mathrm{~b}$ and $\mathrm{c}$ ). Livers took on the characteristic black color in both $\mathrm{Bid}^{\text {flo/flo }}$ and $\mathrm{Bid}^{\text {hep }}$ animals (Figure 4a). As expected, H\&E staining showed large hepatic deposits of bilirubin in $\mathrm{Bid}^{\text {flo/flo }}$, as well as $\mathrm{Bid}^{\Delta \text { hep }}$, mice fed with DDC diet (Figure 4a). We did not find any difference in markers of cell proliferation (ki67) and macrophage infiltration $(\mathrm{F} 4 / 80)$ between $\mathrm{Bid}^{\text {flo/flo }}$ and $\mathrm{Bid}^{\Delta \text { hep }}$ liver sections (Figure $4 d$ ). Livers of Bid ${ }^{\text {flo/flo }}$ and Bid ${ }^{\Delta \text { hep }}$ mice injected with CCL4 at 8 weeks of age were morphologically indistinguishable and exhibited similarly elevated serum ALT levels (Figure 4e). In line with previous reports, we found a predominantly necrotic cell death response to CCL4 exposure. Additionally, we detected a low level of apoptotic cell death assessed via TUNEL staining (Figures $4 \mathrm{e}$ and $\mathrm{g}$ ). Interestingly, $\mathrm{Bid}^{\Delta \text { hep }}$ mice showed a reduction in TUNELpositive cells compared with the livers of $\mathrm{Bid}^{\text {flo/flo }}$ mice and this was associated with a reduction in cellular proliferation (Figures $4 \mathrm{e}$ and $\mathrm{g}$ ). Taken together, these data strongly support that Bid deletion in hepatocytes protects from DENinduced liver damage through inhibition of hepatocyte apoptosis.

Hepatocyte Bid is an important contributor to carcinogenesis in a murine model of NAFLD. NAFLD in now the most common form of chronic liver disease in both children and adults in the United States and its incidence and prevalence are increasing to epidemic proportions around the world. ${ }^{15}$ As with other liver diseases that cause cirrhosis, NAFLD increases the risk of liver cancer and HCC and is now the leading cause of obesity-related cancer deaths in middleaged men in the United States. Hepatocyte apoptosis has emerged as a central mechanism involved in disease progression in NAFLD. ${ }^{16}$ To examine whether Bid deletion in hepatocytes also regulate carcinogenesis in NAFLD, we used a human pathophysiologically relevant model induced by feeding mice a choline-deficient amino acid (CDAA) defined diet that induces in a time-dependent manner the 
a
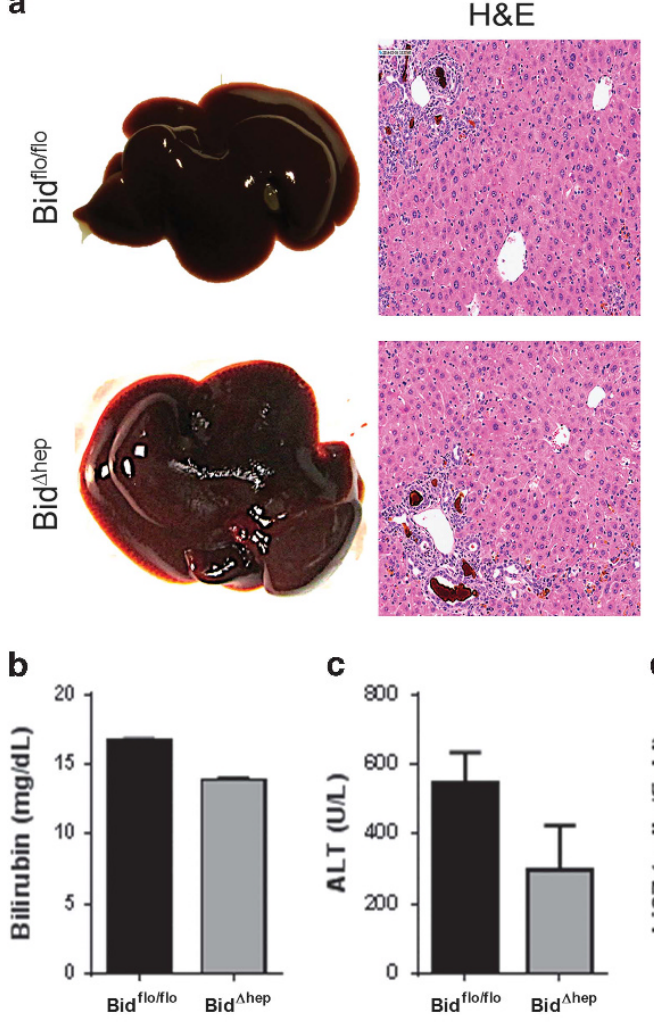

e
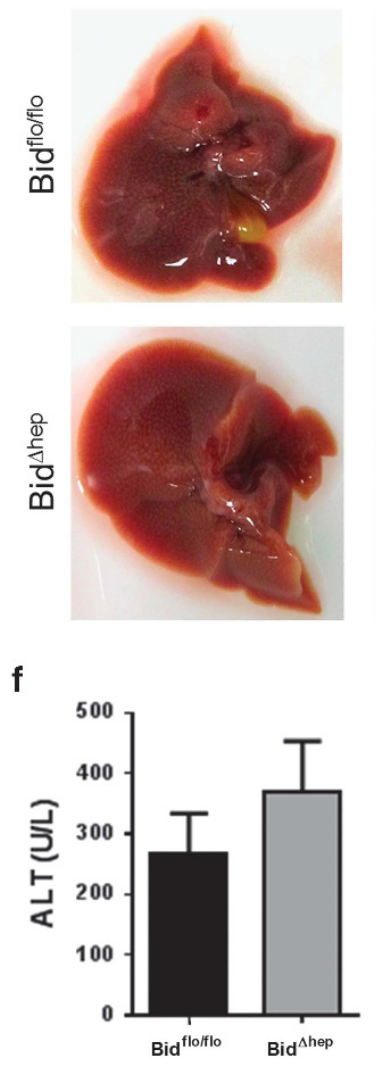

$H \& E$
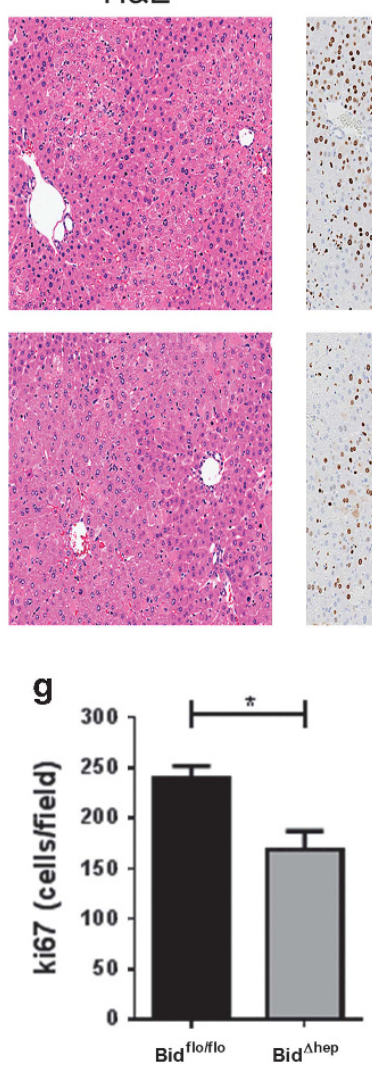

Ki67
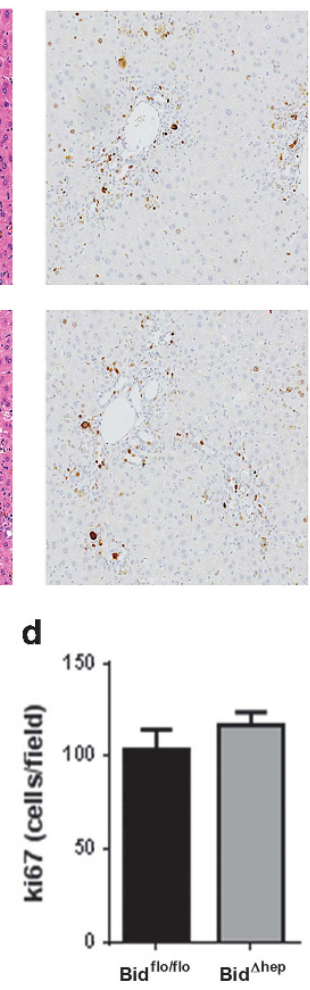

Ki67
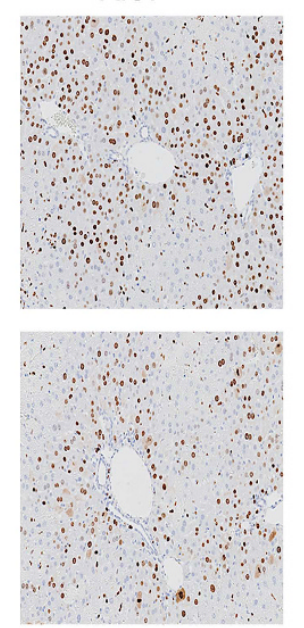

$\mathrm{F} 4 / 80$
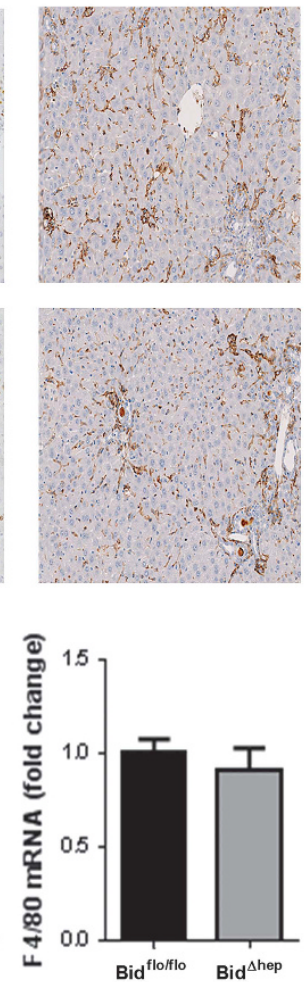

F4/80
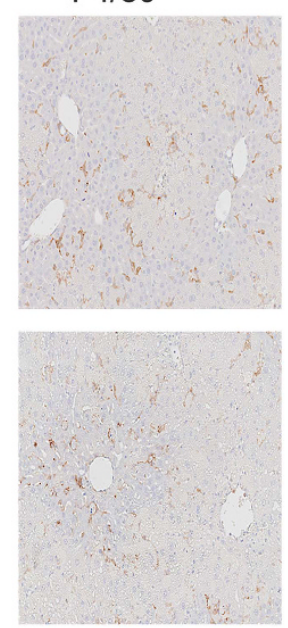

TUNEL
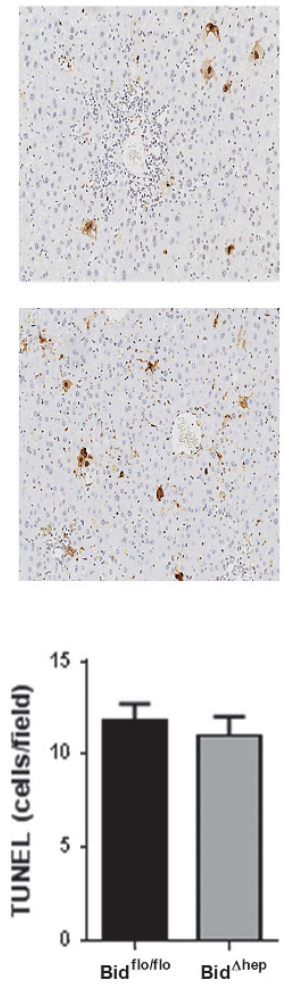

TUNEL
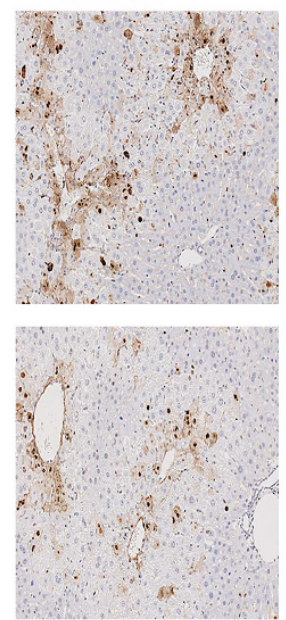
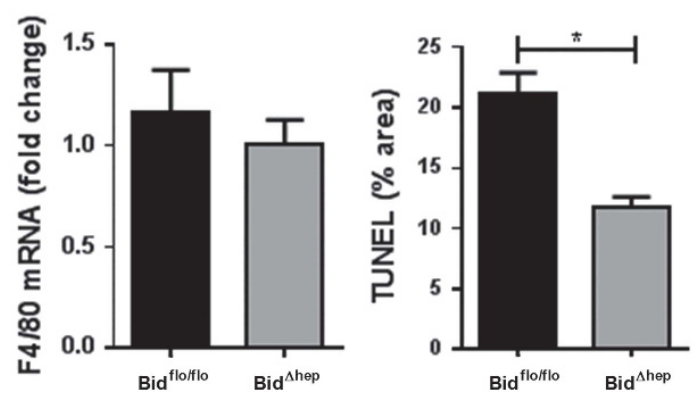
various stages of the disease from hepatic steatosis to steatohepatitis to $\mathrm{HCC} .{ }^{17} \mathrm{C} 57 \mathrm{bl} / 6$ background $\mathrm{Bid}^{\text {hep }}$ and wild-type (WT) mice were fed a CDAA diet. After 48 weeks on

a
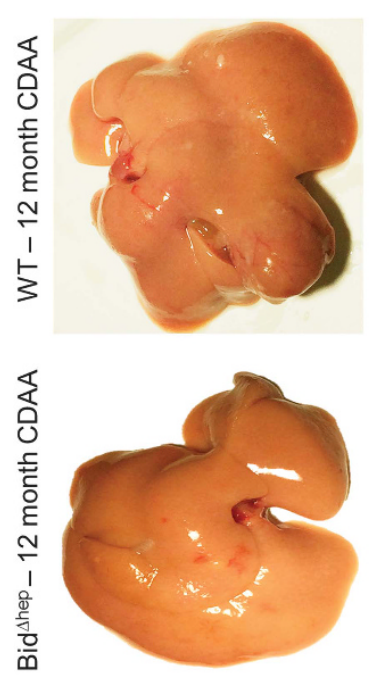

H\&E (5x)
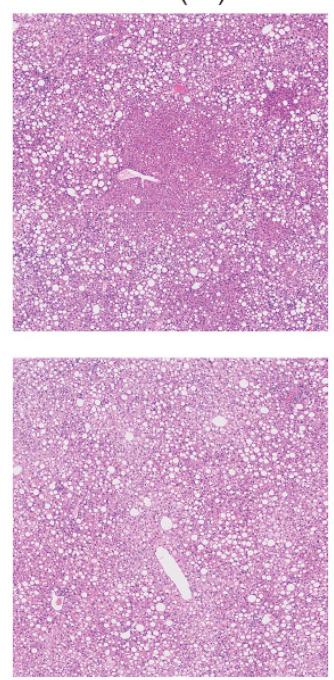

this diet no significant differences in liver and body weight measurements were noted between $\mathrm{Bid}^{\Delta \text { hep }}$ mice and to WT animals (Figure 5d). Importantly, we observed macroscopic

d

\begin{tabular}{|c|c|c|c|}
\hline & \multicolumn{2}{|c|}{ CDAA - 12 month } & \multirow[t]{2}{*}{$p$-value } \\
\hline & WT & $\mathrm{Bid}^{\text {shep }}$ & \\
\hline number & 9 & 16 & \\
\hline body weight (g) & $48.84+/-2.11$ & $47.33+/-0.81$ & n.s. \# \\
\hline liver weight (g) & $3.88+/-0.23$ & $3.81+/-0.21$ & n.s. \# \\
\hline tumor incidence & $4 / 9$ & $2 / 16$ & 0.097 \#\# \\
\hline tumor load & $4.2+/-1.80$ & $1.75+/-1.25$ & $<0.05 \#$ \\
\hline
\end{tabular}

e

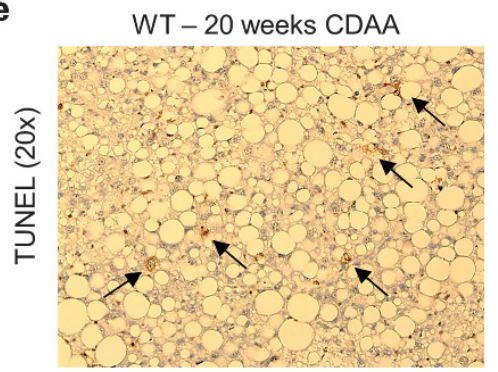

$\mathrm{Bid}^{\Delta h e p}-20$ weeks CDAA

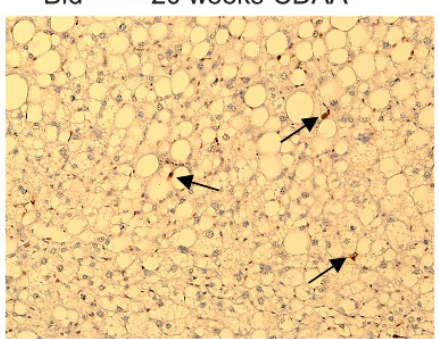

b
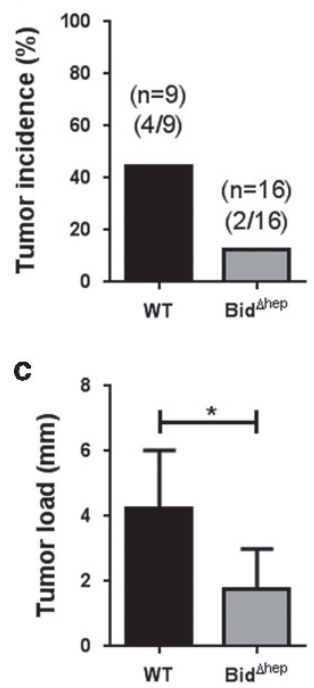

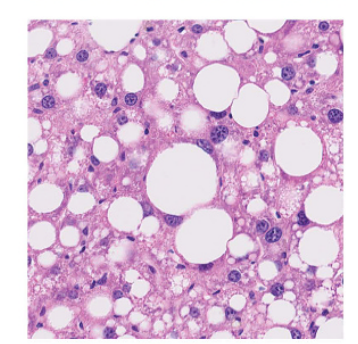

$H \& E(40 x)$

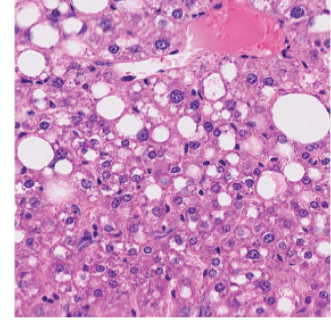


( $\geq 3 \mathrm{~mm}$ ) tumors in 4 out of 9 WT animals corresponding to an incidence level fourfold greater than in $\mathrm{Bid}^{\text {hep }}$ animals, which presented with tumors $\geq 3 \mathrm{~mm}$ in 2 out of 16 animals (Figures $5 a$ and $b$ ). Consistent with these results, the tumor load was significantly decreased in $\mathrm{Bid}^{\Delta \text { hep }}$ animals when compared with WT mice (Figure 5c). Quantification of TUNEL-positive hepatocytes in mice fed with CDAA diet over a 20-week time course revealed a significant reduction in $\mathrm{Bid}^{\Delta \text { hep }}$ mice when compared with WT mice (Figure 5e).

\section{Discussion}

The key findings of the present study relate to the role of hepatocyte Bid in modulation of hepatocarcinogenesis. Our results demonstrate that hepatocyte-specific Bid deletion protects from tumorigenesis in two human relevant murine models of HCC. Livers of $\mathrm{Bid}^{\Delta \text { hep }}$ mice showed a marked reduction in cell death and compensatory proliferation accompanied by a marked reduction in inflammatory response in the acute phase after DEN injections. This was in part a consequence of reduced secondary necrosis upon DEN treatment in mice with hepatic Bid deletion. While hepatocyte Bid deletion is dispensable in liver damage and compensatory proliferation triggered by predominantly necrotic or cholangiopathic injury. Moreover, livers of $\mathrm{Bid}^{\Delta \text { hep }}$ mice were further protected from tumorigenesis in a murine model of NAFLDassociated HCC.

Development of HCC is a complicated process with numerous contributing factors. The role of BID or other proteins involved in the apoptotic machinery has been attributed to their impact on cell proliferation, cell-cycle interactions, influence of apoptotic cell death with consequential secondary necrosis and inflammation. BID, which is normally expressed in the liver, ${ }^{18}$ and other BCL-2 family members, which are not found in the healthy liver, ${ }^{19}$ were recognized to affect cell proliferation in addition to cell survival. ${ }^{20,21}$ It is well known how BCL-2 proteins regulate the apoptotic machinery, but their effects on cell proliferation are still not fully understood. Due to shared protein functions in apoptosis and proliferation of BCL-2 family proteins is seems that the function in the liver is likely to be related to compensatory proliferation. ${ }^{22,23}$ Previous studies in globally deficient BID mice, or in mice with $\mathrm{Bcl}-2$ overexpression, showed impairment in cell proliferation. ${ }^{21,24,25}$ However, global Bid deficiency by itself can lead to an increased incidence of chronic myelomonocytic leukemia in aged mice and similar to this, Bad deficiency has been reported to promote the development of lymphoid tumors either spontaneously or in response to sublethal radiation. ${ }^{26,27}$ On the other hand, overexpression of $\mathrm{Bcl}-2$ and $\mathrm{Bcl}-\mathrm{XL}$ proteins with known antiapoptotic functions, promotes tumor development in pancreatic beta-cells, in lymphoid cells and in myeloid cells. ${ }^{28-30}$ In the present study, we addressed the tissue/cell-specific effects of BID in HCC development. We found a profound decrease in HCC development induced by DEN administration, and as early as $48 \mathrm{~h}$ after high-dose DEN injection we found a marked decrease in hepatocyte proliferation markers.

An even more prominent effect of BID deficiency was observed in assessing hepatocellular apoptosis, which is a common feature in various chronic liver diseases that result in cirrhosis and hepatocarcinogenesis. An increase in hepatocyte cell death by apoptosis is typically present in patients with NAFLD and in experimental models of this disease, ${ }^{31,32}$ The two fundamental pathways of apoptosis, the extrinsic (death receptor-mediated) and intrinsic (organelleinitiated) pathways, are involved. ${ }^{31}$ The results of the current study demonstrate that selective deletion of Bid in hepatocytes protects from DEN-induced tumorigenesis. Due to the fact that the initial cellular damage occurring within the first days of DEN injection is known to be of major importance in HCC induction, ${ }^{7}$ we assessed the livers of mice $48 \mathrm{~h}$ after DEN injection and observed that $\mathrm{Bid}^{\text {hep }}$ mouse livers were protected from the hepatocyte cell death, compensatory proliferation and inflammatory changes that typically result from DEN administration. These effects appeared to be specific for apoptotic stressors as minimal or no effects were observed when either a mainly necrotic or a cholangiopathic injury was used. Although based on observations in developing animals, and in vitro studies in immortalized cell lines, apoptosis has been perceived to be non-inflammatory, it has become apparent that a pathological increase in apoptosis in the context of chronic diseases may directly or indirectly promote inflammation. ${ }^{33,34}$ Chronic inflammation is an established element of HCC development and progression is associated with proliferation, angiogenesis and metastasis. ${ }^{35}$ The concept of secondary necrosis as the natural outcome of the apoptotic program is extended by our current results and we now demonstrate that the protection from hepatocyte apoptosis seen in $\mathrm{Bid}^{\Delta \text { hep }}$ mice is associated with a marked decrease in pro-inflammatory cytokines and inflammatory activity in liver tissue. Although a direct effect of Bid depletion in inflammation, as suggested in earlier studies, ${ }^{36}$ cannot be completely ruled out, other studies have put into significant question a potentially direct effect of Bid in inflammation independent of its apoptotic function. ${ }^{37}$

To examine whether Bid deletion in hepatocytes also regulates carcinogenesis in NAFLD, the fastest growing cause of HCC and a disease characterized by increased hepatocyte apoptosis, we used a human pathophysiologically relevant model of disease induced by feeding mice a CDAA defined diet that induces in a time-dependent manner the various stages of NAFLD from hepatic steatosis to steatohepatitis to $\mathrm{HCC}^{17}$ Our findings demonstrate that $\mathrm{Bid}^{\text {hep }}$ was protected from $\mathrm{HCC}$ development after 48 weeks on this diet in a process that was independent of lipid overloading of the liver and associated with a decrease in hepatocyte apoptosis.

In summary, the present study identifies hepatocyte Bid as an important contributor to HCC in two relevant experimental models, as well as provides important data supporting the modulation of hepatocyte apoptosis during chronic liver injury as a novel target for therapeutic intervention in those conditions in which dysregulated apoptosis is an important feature of disease.

\footnotetext{
Materials and Methods

Animal models

$\mathrm{Bid}^{\Delta h e p}$ mice: $\mathrm{Bid}^{\Delta \text { hep }}$ mice were generated as previously described. On a C57b//6 background, exons 2-4 of the Bid gene were flanked with loxP sites via transgenic manipulation and bred with a mouse expressing Cre recombinase driven by the Albumin promoter. ${ }^{14}$
} 
Diethylnitrosamine: DEN injections were performed as previously described. To induce liver tumorigenesis 14-day-old Bid ${ }^{\text {hep }}$ and Bid ${ }^{\text {flofllo }}$ mice were injected i.p. with $25 \mathrm{mg} / \mathrm{kg}$ BW DEN (Sigma-Aldrich, St. Louis, MO, USA). ${ }^{38}$ Acute effects of DEN were studied using 8-week-old Bid ${ }^{\text {Ahep }}$ and Bid ${ }^{\text {flofllo }}$ mice that were injected i.p. with $100 \mathrm{mg} / \mathrm{kg} \mathrm{BW}$ DEN.

$D D C$ diet model: Eight-week-old $\mathrm{Bid}^{\Delta \text { hep }}$ and Bid ${ }^{\text {floflo }}$ mice were fed a DDC diet for 2 weeks, following previously described published methods. ${ }^{39}$

Carbon tetrachloride model: CCL4 injections were performed as previously described. ${ }^{40}$ Eight-week-old Bid ${ }^{\Delta \text { hep }}$ and Bid ${ }^{\text {floflo }}$ mice were injected intraperitoneally with a single prediluted (1:3 in olive oil) dose $(1 \mu \mathrm{l} / \mathrm{g})$ of CCL4.

CDAA model: Eight-week-old $\mathrm{Bid}^{\mathrm{Ahep}}$ and WT mice were fed a CDAA diet (Dyets, Bethlehem, PA, USA) over a 12-month period. ${ }^{17}$

University of California San Diego (USCD) Institutional Animal Care and Use Committee approved protocols. All mice were maintained in filter topped cages with free access to food and water at UCSD according to the NIH guidelines.

Primary cell isolation. Primary hepatocytes were isolated using a two-step perfusion method as previously published. ${ }^{41}$ Briefly, mice were deeply anesthetized, the abdominal cavity was opened and the portal vein was cannulated. The liver was then sequentially perfused with ethylene glycol tetraacetic acid (EGTA) and collagenase D. Hepatocytes were seeded on collagen-coated culture dishes and used for experiments on the following day. To mark hepatocytes for further investigation, propidium iodide and Hoechst 33342 (Life Technologies, Grand Island, NY, USA) were added to the cultured cells. Microphotographs of cultured hepatocytes were assessed using a high content imaging system (Operetta, Perkin Elmer, Waltham, MS, USA).

LDH measurement. LDH was quantified using a commercially available kit (Cytotox 96, Promega, Madison, WI, USA) in accordance with the manufacturer's instructions.

Liver sample preparation. At the selected time interval, mice were anesthetized (ketamine $60 \mathrm{mg} / \mathrm{kg}$ plus xylazine $10 \mathrm{mg} / \mathrm{kg}$ intraperitoneal), blood samples were collected via cardiac puncture and the peritoneal and thoracic cavities opened. The liver was harvested and tissue was divided: (i) a representative section was fixed in $10 \%$ formalin for $24 \mathrm{~h}$ and embedded in paraffin or directly frozen in embedding medium for frozen tissue sections, (ii) samples of $50 \mu \mathrm{g}$ were placed in $500 \mu \mathrm{l}$ of RNAlater Solution (Life Technologies) and (iii) remaining liver tissue was quickly frozen in liquid nitrogen and stored in $-80^{\circ} \mathrm{C}$

Histology and immunohistochemistry. Immunohistochemistry staining for F4/80 (a global marker for murine macrophages) (AbD Serotec, Hercules, CA, USA), ki67 (GeneTex, Irvine, CA, USA) and PCNA (Abcam, Cambridge, MA, USA) was performed in formalin-fixed, paraffin-embedded liver sections according to the manufacturer's instruction. TUNEL assay was performed as per manufacturer's instructions (ApopTag Peroxidase In Situ Apoptosis Detection Kit, Millipore, Billerica, MA, USA). Sample slides were imaged at the UCSD Microscopy Core using the Hamamatsu NanoZoomer 2.0-HT.

Real-time PCR. Total RNA was isolated from liver tissue and analyzed as previously described. ${ }^{42}$ The sequences of the primers used for quantitative PCR are given in Supplementary Table 1.

Immunoblot analysis. Immunoblot analysis was performed as previously described. ${ }^{42}$ Anti-Bid (Cell Signaling, Boston, MA, USA) antibody was used in combination with appropriate peroxidase-conjugated secondary antibody. Protein load was verified with an actin antibody (dilution $1: 10$ 000) (Santa Cruz, Dallas, TX USA). Bands were visualized with the enhanced chemiluminescence reagent and digitized using a CCD camera (ChemiDoc, Bio-Rad, Hercules, CA, USA). Expression intensity was quantified by ImageLab (Bio-Rad).

Liver function tests. Serum values of alanine aminotransferase (ALT) were measured at the end of DEN exposure timelines ( $48 \mathrm{~h}, 9$ months) according to the manufacturer's instruction (Infinity ALT, Thermo Scientific, Waltham, MA, USA).

Unless stated otherwise, all other chemicals were purchased from Sigma-Aldrich.
Statistical analyses. Analyses were performed with Graph Pad (version 5.03; Graph Pad, Graph Pad Software Inc., La Jolla, CA, USA). The significance level was set at $\alpha=5 \%$ for all comparisons. If data or log transformation of data had approximately normal distributions, then the interaction or main effects were tested by ANOVA. Least squared means were used for group comparisons. If data deviated from the normal distribution, then non-parametric Mann-Whitney tests were used for group comparisons. Fisher's exact test was applied to compare tumor incidences. Unless otherwise stated, data are expressed as mean \pm S.E.M. or as absolute number or percentage for categorical variables.

\section{Conflict of Interest}

The authors declare no conflict of interest.

Acknowledgements. We also thank Jennifer Santini at the UCSD Microscopy Core, which is supported by the UCSD Neuroscience Microscopy Shared Facility grant (P30 NS047101). The work was funded by NIH (DK076852 and DK082451 to AEF, CA155120-02 and CA118165-06 to MK), German Research Foundation (DFG-grant 173/2-1 to AW), Superfund Basic Research Program (P42ES010337 to MK), California Institute for Regenerative Medicine Stem Cell Training Grant II (TG2-01154 to JFB). MK holds the Ben and Wanda Hildyard Chair for Mitochondrial and Metabolic Diseases and is an American Cancer Society Research Professor.

\section{Author contributions}

AW, CDJ, JFB, MK and AEF conceived and designed the experiments. AW, CDJ, JFB, $A E$, and DP performed the experiments. AW, CDJ, AE, DP and AEF analyzed the data. AW, CDJ, JFB, MK and AEF wrote the paper.

1. Bruix J, Boix L, Sala M, Llovet JM. Focus on hepatocellular carcinoma. Cancer Cell 2004; 5 : 215-219.

2. Bosch FX, Ribes J, Diaz M, Cleries R. Primary liver cancer: worldwide incidence and trends. Gastroenterology 2004; 127: S5-S16.

3. Fox JG, Feng Y, Theve EJ, Raczynski AR, Fiala JL, Doernte AL et al. Gut microbes define liver cancer risk in mice exposed to chemical and viral transgenic hepatocarcinogens. Gut 2010; 59: 88-97.

4. Verna L, Whysner J, Williams GM. N-nitrosodiethylamine mechanistic data and risk assessment: bioactivation, DNA-adduct formation, mutagenicity, and tumor initiation. Pharmacol Ther 1996; 71: 57-81.

5. Naugler WE, Sakurai T, Kim S, Maeda S, Kim K, Elsharkawy AM et al. Gender disparity in liver cancer due to sex differences in MyD88-dependent IL-6 production. Science 2007; 317: 121-124.

6. Fan Y, Boivin GP, Knudsen ES, Nebert DW, Xia Y, Puga A. The aryl hydrocarbon receptor functions as a tumor suppressor of liver carcinogenesis. Cancer Res 2010; 70: 212-220.

7. Maeda S, Kamata H, Luo JL, Leffert H, Karin M. IKKbeta couples hepatocyte death to cytokine-driven compensatory proliferation that promotes chemical hepatocarcinogenesis. Cell 2005; 121: 977-990.

8. Adams LA, Lindor KD. Nonalcoholic fatty liver disease. Ann Epidemiol 2007; 17: 863-869.

9. Ratziu V, Bonyhay L, Di Martino V, Charlotte F, Cavallaro L, Sayegh-Tainturier MH et al. Survival, liver failure, and hepatocellular carcinoma in obesity-related cryptogenic cirrhosis. Hepatology 2002; 35: 1485-1493.

10. Wree A, Kahraman A, Gerken G, Canbay A. Obesity affects the liver - the link between adipocytes and hepatocytes. Digestion 2011; 83: 124-133.

11. Powell EE, Cooksley WG, Hanson R, Searle J, Halliday JW, Powell LW. The natural history of nonalcoholic steatohepatitis: a follow-up study of forty-two patients for up to 21 years. Hepatology 1990; 11: 74-80.

12. Cotrim HP, Parana R, Braga E, Lyra L. Nonalcoholic steatohepatitis and hepatocellular carcinoma: natural history? Am J Gastroenterol 2000; 95: 3018-3019.

13. Ertle J, Dechene A, Sowa JP, Penndorf V, Herzer K, Kaiser G et al. Non-alcoholic fatty liver disease progresses to hepatocellular carcinoma in the absence of apparent cirrhosis. Int J Cancer 2011; 128: 2436-2443.

14. Lazic M, Eguchi A, Berk MP, Povero D, Papouchado B, Mulya A et al. Differential regulation of inflammation and apoptosis in Fas-resistant hepatocyte-specific Bid-deficient mice. $J$ Hepatol 2014; 61: 107-115.

15. Vernon G, Baranova A, Younossi ZM. Systematic review: the epidemiology and natural history of non-alcoholic fatty liver disease and non-alcoholic steatohepatitis in adults. Aliment Pharmacol Ther 2011; 34: 274-285.

16. Alkhouri $\mathrm{N}$, Carter-Kent $\mathrm{C}$, Feldstein AE. Apoptosis in nonalcoholic fatty liver disease: diagnostic and therapeutic implications. Expert Rev Gastroenterol Hepatol 2011; 5: 201-212.

17. Denda A, Kitayama W, Kishida H, Murata N, Tsutsumi M, Tsujiuchi T et al. Development of hepatocellular adenomas and carcinomas associated with fibrosis in C57BL/6J male mice given a choline-deficient, L-amino acid-defined diet. Jpn J Cancer Res 2002; 93: 125-132 
18. Yin XM, Wang K, Gross A, Zhao Y, Zinkel S, Klocke B et al. Bid-deficient mice are resistant to Fas-induced hepatocellular apoptosis. Nature 1999; 400: 886-891.

19. Vail ME, Chaisson ML, Thompson J, Fausto N. Bcl-2 expression delays hepatocyte cell cycle progression during liver regeneration. Oncogene 2002; 21: 1548-1555.

20. Cory S, Huang DC, Adams JM. The Bcl-2 family: roles in cell survival and oncogenesis. Oncogene 2003; 22: 8590-8607.

21. Bai L, Ni HM, Chen X, DiFrancesca D, Yin XM. Deletion of Bid impedes cell proliferation and hepatic carcinogenesis. Am J Pathol 2005; 166: 1523-1532.

22. Janumyan YM, Sansam CG, Chattopadhyay A, Cheng N, Soucie EL, Penn LZ et al. $\mathrm{Bcl}-\mathrm{xL} / \mathrm{Bcl}-2$ coordinately regulates apoptosis, cell cycle arrest and cell cycle entry. EMBO J2003; 22: 5459-5470.

23. Cheng N, Janumyan YM, Didion L, Van Hofwegen C, Yang E, Knudson CM. Bcl-2 inhibition of T-cell proliferation is related to prolonged T-cell survival. Oncogene 2004; 23: 3770-3780.

24. Pierce RH, Vail ME, Ralph L, Campbell JS, Fausto N. Bcl-2 expression inhibits liver carcinogenesis and delays the development of proliferating foci. Am J Pathol 2002; 160: 1555-1560.

25. Vail ME, Pierce RH, Fausto N. Bcl-2 delays and alters hepatic carcinogenesis induced by transforming growth factor alpha. Cancer Res2001; 61: 594-601.

26. Zinkel SS, Ong CC, Ferguson DO, Iwasaki H, Akashi K, Bronson RT et al. Proapoptotic BID is required for myeloid homeostasis and tumor suppression. Genes Dev 2003; 17 : 229-239

27. Ranger AM, Zha J, Harada H, Datta SR, Danial NN, Gilmore AP et al. Bad-deficient mice develop diffuse large B cell lymphoma. Proc Natl Acad Sci USA 2003; 100: 9324-9329.

28. Pelengaris S, Khan M, Evan GI. Suppression of Myc-induced apoptosis in beta cells exposes multiple oncogenic properties of Myc and triggers carcinogenic progression. Cell 2002; 109: 321-334.

29. Strasser A, Harris AW, Bath ML, Cory S. Novel primitive lymphoid tumours induced in transgenic mice by cooperation between myc and bcl-2. Nature 1990; 348: 331-333.

30. Kogan SC, Brown DE, Shultz DB, Truong BT, Lallemand-Breitenbach V, Guillemin MC et al. $\mathrm{BCL}-2$ cooperates with promyelocytic leukemia retinoic acid receptor alpha chimeric protein
(PMLRARalpha) to block neutrophil differentiation and initiate acute leukemia. J Exp Med2001; 193: 531-543.

31. Wree A, Broderick L, Canbay A, Hoffman HM, Feldstein AE. From NAFLD to NASH to cirrhosis-new insights into disease mechanisms. Nat Rev Gastroenterol Hepatol 2013; 10 627-636.

32. Eguchi A, Wree A, Feldstein AE. Biomarkers of liver cell death. J Hepatol 2014; 60 : 1063-1074.

33. Silva MT. Secondary necrosis: the natural outcome of the complete apoptotic program. FEBS Lett 2010; 584: 4491-4499.

34. Vanden Berghe T, Vanlangenakker N, Parthoens E, Deckers W, Devos M, Festjens N et al. Necroptosis, necrosis and secondary necrosis converge on similar cellular disintegration features. Cell Death Differ 2010; 17: 922-930.

35. Grivennikov SI, Greten FR, Karin M. Immunity, inflammation, and cancer. Cell 2010; 140: 883-899.

36. Yeretssian G, Correa RG, Doiron K, Fitzgerald P, Dillon CP, Green DR et al. Non-apoptotic role of BID in inflammation and innate immunity. Nature 2011; 474: 96-99.

37. Nachbur U, Vince JE, O'Reilly LA, Strasser A, Silke J. Is BID required for NOD signalling? Nature 2012; 488: E4-E6 discussion E6-8.

38. He G, Dhar D, Nakagawa H, Font-Burgada J, Ogata $H$, Jiang $Y$ et al. Identification of liver cancer progenitors whose malignant progression depends on autocrine IL-6 signaling. Cell 2013; 155: 384-396.

39. Anakk S, Bhosale M, Schmidt VA, Johnson RL, Finegold MJ, Moore DD. Bile acids activate YAP to promote liver carcinogenesis. Cell Rep 2013; 5: 1060-1069.

40. Moles A, Murphy L, Wilson CL, Chakraborty JB, Fox C, Park EJ et al. A TLR2/S100A9/ CXCL-2 signaling network is necessary for neutrophil recruitment in acute and chronic liver injury in the mouse. J Hepatol 2014; 60: 782-791.

41. Li WC, Ralphs KL, Tosh D. Isolation and culture of adult mouse hepatocytes. Methods Mol Biol 2010; 633: 185-196.

42. Wree A, Eguchi A, McGeough MD, Pena CA, Johnson CD, Canbay A et al. NLRP3 inflammasome activation results in hepatocyte pyroptosis, liver inflammation and fibrosis. Hepatology 2013; 59: 898-910.

\section{Supplementary Information accompanies this paper on Cell Death and Differentiation website (http://www.nature.com/cdd)}

